\title{
Wastewater from Fish Farms for Producing Eucalyptus grandis Seedlings
}

\author{
Dalva Paulus $^{1}$ (D), Ivan Carlos Zorzzi ${ }^{1}$ (D), \\ Fabiana Rankrape ${ }^{1}$ (i), Gilmar Antônio Nava ${ }^{1}$ (1) \\ ${ }^{1}$ Universidade Tecnológica Federal do Paraná (UTFPR), Dois Vizinhos, PR, Brasil
}

\begin{abstract}
This work aimed to evaluate the development and quality of Eucalyptus grandis seedlings produced with different dosages of wastewater from fish farming. The experiment was arranged in a completely randomized design with five treatments and four replicates. The treatments were fish wastewater (FW); daily nutritional solution (DNS), combinations of $50 \% \mathrm{DNS}+50 \% \mathrm{FW}$; $25 \% \mathrm{DNS}+75 \% \mathrm{FW}$ and solution with weekly application (WNS). The best growth and development results of the eucalyptus seedlings were observed for the solutions applied daily and weekly. The 50\% DNS + 50\% FW combination did not differ from daily and weekly nutritional solutions for Dickson's quality index. Fertigation only with wastewater from fish farming resulted in lower growth and development of the seedlings, but the use of the combination of $50 \% \mathrm{FW}+50 \% \mathrm{DNS}$ enabled the production of seedlings of similar quality to those fertigated with nutritional solutions.
\end{abstract}

Keywords: eucalyptus, forest nutrition, water reuse. 


\section{INTRODUCTION}

Due to the growing concern with conservation and environmental sustainability, the usage of effluents in other activities has become an important option. Among effluents, we can mention the intensification of fish production which generates wastewater. When inappropriately designed, fish farming/ production can lead to an increase in environmental impact in terms of waste production and water use (Mariscal-Lagarda et al., 2012). Faced with this environmental problem, studies on the reutilization of wastewater in agricultural activities, such as in the production of seedlings in commercial nurseries, represents a possibility of a source of nutrients and sustainable production.

The Eucalyptus genus is the most used in forest plantations in Brazil due to its high productivity and flexibility for soil and climate conditions (Gonçalves et al., 2008), being an important raw material for the paper, cellulose, charcoal and timber industry sectors. Due to this demand scenario of the timber sector, the production of quality seedlings is an important factor to increase the survival rate and initial growth (Gomes et al., 2002). The quality of seedlings can mainly be affected by the genetic components, substrates and water, and nutritional management (Silva et al., 2012).

Nutritional factors can be supplied with adequate fertilization, thus being an indispensable factor for producing quality seedlings (Assenheimer, 2009). However, for Silveira et al. (2003) there is a lack of information regarding the dose and the adequate nutrient ratio to be applied in fertilization at different stages of Eucalyptus seedling development. Most forest nurseries standardize the application of independent fertilizers for the different development stages of the seedlings. Thus, it is necessary to study doses, stages and application forms, as well as alternative sources of nutrients for use in the production of forest seedlings.

The issue of the environmental impact of nutrient-rich water discharges into rivers or the need to treat them and the high concentration of nutrients in fish-breeding water has led to new studies with effluents, which may reduce the normal concentration of nutrients applied to the substrate in producing seedlings in nurseries. Some studies indicate the possibility of using wastewater from fish farming in lettuce cultivation (Lactuca sativa)
(Cortez et al., 2009) or in the production of tomato seedlings (Solanum lycopersicum) (Rodrigues et al., 2010). However, there is a shortage of studies that seek to associate fish farming and forest seedling production.

Adequate nutritional management enabled the growth of horse whip (açoita-cavalo) (Luehea divaricata mart.) seedlings in height, diameter and accumulation of biomass (Ceconi et al., 2006). In this context, several works have been developed seeking to improve quality and reduce production costs of seedlings (Simões \& Silva, 2010), considering that the use of wastewater from fish farming in seedling production can reduce costs and minimize the negative impacts caused by their disposal.

The objective of this work was to evaluate the development and quality of Eucalyptus grandis W. Hill ex Maiden seedlings produced with different doses of wastewater from fish farming. Therefore, the hypotheses formed were: $i)$ the wastewater benefits the growth and development of $E$. grandis seedlings; ii) the wastewater meets the nutritional demand of eucalyptus seedlings; iii) the wastewater can be an alternative for reuse in eucalyptus seedling production. It is hoped to determine new techniques of seedling production using tilapia wastewater as a source of nutrients, which reduces the environmental impact of the effluent from this production system.

\section{MATERIALS AND METHODS}

The experiment was carried out in the experimental area of the Universidade Tecnológica Federal do Paraná, Dois Vizinhos Campus in the Olericultura Sector

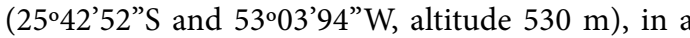
protected environment of a high tunnel greenhouse, covered with 150 microns of plastic film. The experiment was conducted from January to May 2016.

First, $125 \mathrm{~cm}^{3}$ polypropylene tubes filled with Carolina Soil ${ }^{\circ}$ commercial substrate were used, with the major components being decomposed pinus shell and expanded vermiculite. For sowing, in 2015, ten commercial grade with F1 improvement grade (LCFA004) cultivar seeds per Eucalyptus grandis W. Hill Ex Maiden tube were obtained from the Instituto de Pesquisas e Estudos Florestais (IPEF) of the clonal orchard seeds (PCS) in Piracicaba, São Paulo. Thinning was performed at 30 DAS, leaving only one plant per tube. 
The fish species used was tilapia (Oreochromis niloticus). The fish were kept in a nursery dug with a capacity of 1,000 liters of water, which is renewed daily at a percentage of $50 \%$ of the volume, with a $1 \mathrm{CV}$ motor pump. In order to keep oxygen levels in the nursery water, submersible pumps were used to mix the water every 15 minutes. Oxygen concentration was monitored with a portable oximeter twice weekly at three points in the tank. The mean oxygen value were $26.6 \mathrm{mg} \mathrm{L}^{-1}$.

The initial and final fish masses were 2.9 and $7.9 \mathrm{~kg}$, respectively. The fish mass was quantified every 30 days and the amount of feed adjusted, considering a $3 \%$ supply of the live fish mass divided into two daily rations of commercial Anhambi ${ }^{\circledR}$.

The experiment was arranged in a completely randomized design with five treatments and four replicates. Each experimental unit was composed of 96 seedlings. The treatments were fish wastewater (FW); daily nutrient solution (DNS) composed of the amount of $0.45 \mathrm{~g} \mathrm{~L}^{-1}$ of calcium nitrate; $0.30 \mathrm{~g} \mathrm{~L}^{-1}$ of ammonium nitrate; $0.25 \mathrm{~g} \mathrm{~L}^{-1}$ of monoammonium phosphate; $0.30 \mathrm{~g} \mathrm{~L}^{-1}$ of potassium nitrate; $0.25 \mathrm{~g} \mathrm{~L}^{-1}$ of magnesium sulfate; $0.25 \mathrm{~g} \mathrm{~L}^{-1}$ of ammonium sulfate; $0.50 \mathrm{~g} \mathrm{~L}^{-1}$ of boric acid; combinations of $50 \% \mathrm{DNS}+50 \% \mathrm{FW} ; 25 \% \mathrm{DNS}+75 \% \mathrm{FW}$; and weekly nutrient solution (WNS), described by Gonçalves (2005) and constituting the base application (to fill the tubes): $715 \mathrm{~g}$ of ammonium sulphate and $577 \mathrm{~g}$ of monopotassium phosphate to $20,00050 \mathrm{~cm}^{3}$ tubes and fertilization with $1,000 \mathrm{~g}$ of ammonium sulphate $+300 \mathrm{~g}$ of potassium chloride per 100 liters of water, used to fertigate 10,000 tubes weekly, intercalating the ammonium sulphate and potassium chloride applications. The dosages were all corrected for the number and volume of treatment tubes applied.

The treatment applications started at 45 DAS, using a watering can with daily frequency, and maintaining an irrigation volume of $1 \mathrm{~mm} \mathrm{day}^{-1}$. The rest of the water demand was treated using a sprinkler irrigation system, maintaining a total liquid volume of $6 \mathrm{~mm} \mathrm{dia}^{-1}$. For the treatment with weekly application, pure water was used in order to maintain the liquid irrigation volume.

The analyzed variables were shoot height, stem diameter, green mass, and shoot and root dry mass at $60,75,90,105$ and 120 days after sowing. Plant height was determined with a millimeter ruler from the stem base to the apex of the plant. The diameter measurement was performed using a digital caliper at the stem height. A precision scale $(0.0001 \mathrm{~g})$ was used to determine the green and dry mass. The roots were washed in water to separate the substrate and the material (both roots and shoot) was placed in a forced air circulation oven at $55^{\circ} \mathrm{C} \pm 3$ until constant mass was reached. Ten plants per experimental unit were used to determine the variables described above.

Leaf area, length of the largest root and the Dickson quality index (DQI) were also evaluated at the end of the experiments (120 DAS). The length of the largest root was obtained with a millimetered ruler, measuring from the stem apex to the end of the longest root. The leaf area was determined with foliar area meter (CID Bio-Science, model CI-202, with photometric cell). The Dickson Quality Index was calculated based on the equation, $\mathrm{DQI}=\mathrm{TDM} /(\mathrm{HDR}+\mathrm{SRDMR})$, where total dry mass (TDM), height-to-diameter ratio (HDR) and the shoot to root dry mass ratio (SRDMR) (Dickson et al., 1960).

The macronutrient and micronutrient content in the leaf tissue was determined, and only completely expanded leaves of the middle third of the plant were collected at 120 DAS, according to the methodology described by Malavolta et al. (1997). The meteorological data (temperature and relative air humidity) were obtained from datalogers installed inside the high tunnel. The luminosity values were collected with a luximeter every 30 days during three consecutive days and at three times ( 9 a.m., 12 p.m. and 3 p.m.).

The obtained data were submitted to analysis of variance (F-Test) and the means were compared by the Scott Knott test $(p \leq 0.05)$ using the GENES software program.

\section{RESULTS AND DISCUSSION}

The average temperature during the experiment was $23.6{ }^{\circ} \mathrm{C}$, and the average relative humidity was $74.9 \%$. The temperature during the experiment was found to be within the appropriate ranges for cultivation, whereas the lower basal temperature is $10{ }^{\circ} \mathrm{C}$ (Martins et al., 2007) and the upper basal temperature is $36^{\circ} \mathrm{C}$ (Dye et al., 2004). The average luminosity was 32,500 lux.

There were significant differences between the evaluated treatments regarding height (Table 1). Higher 
growth of the seedlings was observed when fertigated with daily and weekly nutritional solutions with a height increase of $27.7 \mathrm{~cm}$ and $29 \mathrm{~cm}$, respectively, at 120 DAS. Fertigation using the 50\% FW + 50\% DNS combination was the second best treatment with a height of $27.6 \mathrm{~cm}$. The minimum height parameter of transplants to the field is $15 \mathrm{~cm}$ (Wendling \& Dutra, 2010), and all treatments - except the fish wastewater one - met the conditions of adequate height for transplant. Height is an important parameter in the classification and selection of seedlings, as larger seedlings have a greater chance of survival and development in the field (Reis et al., 2008).

The superior height condition of the best treatments at 120 DAS enables evaluating the reduction in the seedling production period, taking into consideration a minimum height of $15 \mathrm{~cm}$ (Wendling \& Dutra, 2010) as an indicator for the moment of transplant, so the seedlings of the best treatments could be transplanted at 105 DAS, reducing the nursery time by 15 days. This information can reduce the cost per seedlings produced, or even increase the rotation of seedlings in the nursery, resulting in a higher seedling production capacity.
In the same way as for height, the highest diameter values were obtained with the use of DNS $(2.46 \mathrm{~mm})$ differing from the WNS $(2.30 \mathrm{~mm})$ and the combination of $50 \% \mathrm{FW}+50 \% \mathrm{DNS}(2.31 \mathrm{~mm})$, which did not differ from the others (Table 1). The treatment with smaller diameter was with wastewater. Adequate diameter values were greater than $2 \mathrm{~mm}$, which indicate adequate seedling formation (Wendling \& Dutra, 2010). Only the wastewater treatment $(0.91 \mathrm{~mm})$ did not produce seedlings with adequate diameter, evidencing the need for complementation with other nutrient sources.

The length of the largest root at 120 DAS was observed in the $75 \% \mathrm{FW}+25 \%$ DNS $(20.9 \mathrm{~cm})$ treatment (Table 2). Regarding leaf area, the highest values were found with the use of WNS $\left(159.4 \mathrm{~cm}^{2}\right)$ and DNS $\left(165.3 \mathrm{~cm}^{2}\right)$, differing from the $50 \% \mathrm{FW}+$ $50 \%$ DNS treatment $\left(123.4 \mathrm{~cm}^{2}\right)$. Leaf area has an important role in vegetal production, enabling greater photoassimilate production. However, when the seedling is transplanted, a larger leaf area can favor water loss by transpiration.

The increase in the leaf area of the plants irrigated with WNS and DNS may be related to the contribution

Table 1. Height and diameter of eucalyptus (Eucalyptus grandis) seedlings in response to the application of different fertigations with fish production wastewater evaluated at 60, 75, 90, 105 and 120 days after sowing. Dois Vizinhos, UTFPR, 2016.

\begin{tabular}{|c|c|c|c|c|c|}
\hline \multirow{2}{*}{ Treatments } & \multicolumn{5}{|c|}{ Height (cm) } \\
\hline & 60 DAS & 75 DAS & 90 DAS & 105 DAS & 120 DAS \\
\hline WNS & $4.2 \mathrm{a}^{\star}$ & $6.0 \mathrm{a}$ & $12.0 \mathrm{a}$ & $26.1 \mathrm{a}$ & $31.9 \mathrm{a}$ \\
\hline DNS & $3.1 \mathrm{~b}$ & $5.1 \mathrm{~b}$ & $11.0 \mathrm{~b}$ & $22.6 \mathrm{~b}$ & $32.1 \mathrm{a}$ \\
\hline $50 \% \mathrm{FW}+\mathbf{5 0} \% \mathrm{WNS}$ & $3.4 \mathrm{~b}$ & $5.7 \mathrm{a}$ & $9.8 \mathrm{c}$ & $21.6 \mathrm{~b}$ & $27.6 \mathrm{~b}$ \\
\hline $75 \% \mathrm{FW}+25 \% \mathrm{WNS}$ & $2.7 \mathrm{~b}$ & $4.5 \mathrm{c}$ & $7.8 \mathrm{~d}$ & $16.4 \mathrm{c}$ & $22.4 \mathrm{c}$ \\
\hline FW & $2.6 \mathrm{~b}$ & $4.4 \mathrm{c}$ & $4.7 \mathrm{e}$ & $5.1 \mathrm{~d}$ & $7.0 \mathrm{~d}$ \\
\hline Mean & 3.2 & 5.1 & 9.1 & 18.3 & 24.2 \\
\hline $\mathrm{CV}(\%)$ & 18.9 & 5.4 & 2.2 & 7.2 & 6.7 \\
\hline \multirow{2}{*}{ Treatments } & \multicolumn{5}{|c|}{ Diameter (mm) } \\
\hline & 60 DAS & 75 DAS & 90 DAS & 105 DAS & $120 \mathrm{DAS}$ \\
\hline WNS & $0.48 \mathrm{a}^{*}$ & $0.79 \mathrm{a}$ & $1.15 \mathrm{a}$ & $1.87 \mathrm{a}$ & $2.30 \mathrm{~b}$ \\
\hline DNS & $0.47 \mathrm{a}$ & $0.79 \mathrm{a}$ & $1.20 \mathrm{a}$ & $1.74 \mathrm{a}$ & $2.46 \mathrm{a}$ \\
\hline $50 \% \mathrm{FW}+\mathbf{5 0} \% \mathrm{WNS}$ & $0.48 \mathrm{a}$ & $0.80 \mathrm{a}$ & $1.07 \mathrm{~b}$ & $1.79 \mathrm{a}$ & $2.31 \mathrm{~b}$ \\
\hline $75 \% \mathrm{FW}+25 \% \mathrm{WNS}$ & $0.40 \mathrm{~b}$ & $0.69 \mathrm{~b}$ & $0.91 \mathrm{c}$ & $1.48 \mathrm{~b}$ & $2.03 \mathrm{c}$ \\
\hline FW & $0.40 \mathrm{~b}$ & $0.66 \mathrm{~b}$ & $0.72 \mathrm{~d}$ & $0.76 \mathrm{c}$ & $0.91 \mathrm{~d}$ \\
\hline Mean & 0.45 & 0.74 & 1.00 & 1.51 & 2.00 \\
\hline $\mathrm{CV}(\%)$ & 4.0 & 4.1 & 4.5 & 6.3 & 4.9 \\
\hline
\end{tabular}

WNS: weekly nutrient solution; DNS: daily nutrient solution; FW: fish wastewater; CV: coefficient of variance; ${ }^{\star}$ means followed by distinct letters in the column differ by the Scott Knott test at $5 \%$ probability. 
of potassium, nitrogen and phosphorus from fertilizer nutrient sources, which are highly required in the initial stages of Eucalyptus seedling development (Pinto et al., 2011), which resulted in greater cell elongation and, consequently, greater leaf expansion.

With regard to the DQI, the DNS (0.122), WNS (0.113) and the combination of $50 \% \mathrm{FW}+50 \%$ DNS (0.121) did not differ (Table 2). Although it was observed that the combination of $50 \% \mathrm{FW}+50 \% \mathrm{WNS}$ did not present the best results for height, diameter or shoot and root dry mass, it did enable forming a balanced seedling in height and biomass accumulation. Gomes \& Paiva (2004) suggest that the minimum DQI value should be greater than 0.20 . Thus, none of the treatments reached this value.

It was observed that the treatments with greater accumulation of fresh and dry shoot mass were for WNS ( 4.7 g plant $\left.^{-1}\right)$ and DNS (4.5 g plant $\left.^{-1}\right)$ (Table 3 ). The treatment with less biomass accumulation was the wastewater. This condition can be associated with the low nitrogen availability provided by the solution and quantified by leaf tissue analysis (Table 5), where the concentrations were below adequate for eucalyptus.

It can also be affirmed that plants with higher leaf area values provide higher photosynthetic rates and consequently higher dry matter accumulation (Rocha et al., 2014). It was observed that treatments with greater leaf area resulted in greater biomass accumulation. According to Carmo et al. (2016), shoot dry mass is related to the development of the stem and amount of leaves. This growth parameter is very important, since the leaves are responsible for the accomplishment of photosynthesis.
In works by Rocha et al. (2014), the authors evaluated the growth and leaf nutrition of Eucalyptus sp. submitted to wastewater from fish farming, public supply and sewage effluent, in which it was reported that the sewage effluent presented greater seedling growth in size and vigor. The authors attributed the gain in growth to the higher nutrient content, mainly nitrogen, present in the sewage effluent in relation to the other types of water. Cerqueira et al. (2017) evaluated the use of effluent from a clonal mini garden as fertilization for clonal eucalyptus seedlings, verifying that the use of this effluent in fertilizing eucalyptus seedlings presented promising results, while it also resulted in seedlings with a higher quality standard which enabled the reuse of the effluent generated in the clonal mini garden.

Significant differences between treatments were found for fresh root mass at 120 DAS, where the best results $\left(2.45 \mathrm{~g} \mathrm{plant}^{-1}\right)$ were found in the $50 \% \mathrm{FW}$ $+50 \%$ DNS solution (Table 4 ). It can be observed that the fertilization with 50\% FW + 50\% DNS favored development of vigorous roots without folding.

According to Kozlowski et al. (1991), the initial growth of the plants in the field depends on photosynthates stored by the seedlings. The largest accumulation of photosynthesis occurs in the seedling shoot. In contrast, when some nutrients such as nitrogen and phosphorus limit plant growth, the roots become a strong drain of carbohydrates, thus causing greater limitation to shoot growth than root growth (Araújo \& Machado, 2006). It was verified that the nitrogen and phosphorus contents in the evaluated treatments did not limit the growth of the eucalyptus seedlings.

Table 2. The highest root length (H.R.L.), leaf area (L.A.) and Dickson Quality Index (D.Q.I.) of Eucalyptus grandis seedlings were evaluated in response to the application of different treatments with wastewater from fish farms evaluated at 60, 75, 90, 105 and 120 days after sowing. Dois Vizinhos, UTFPR, 2016.

\begin{tabular}{cccc} 
Treatments & H.R.L. $(\mathbf{c m})$ & L.A. $\left(\mathbf{c m}^{2}\right)$ & D.Q.I. \\
\hline WNS & $17.8 \mathrm{c}^{*}$ & $165.3 \mathrm{a}$ & $0.113 \mathrm{a}$ \\
DNS & $18.5 \mathrm{c}$ & $159.4 \mathrm{a}$ & $0.122 \mathrm{a}$ \\
\hline $\mathbf{5 0 \%}$ FW + 50\% WNS & $19.9 \mathrm{~b}$ & $123.4 \mathrm{~b}$ & $0.121 \mathrm{a}$ \\
\hline $\mathbf{7 5 \%}$ FW + 25\% WNS & $20.9 \mathrm{a}$ & $84.0 \mathrm{c}$ & $0.097 \mathrm{~b}$ \\
\hline FW & $17.5 \mathrm{c}$ & $12.5 \mathrm{~d}$ & $0.056 \mathrm{c}$ \\
\hline Mean & 18.9 & 108.9 & 0.10 \\
\hline CV $(\%)$ & 3.5 & 10.8 & 9.9 \\
\hline
\end{tabular}

WNS: weekly nutrient solution; DNS: daily nutrient solution; FW: fish wastewater; CV: coefficient of variance; ${ }^{\star}$ means followed by distinct letters in the column differ by the Scott Knott test at 5\% probability. 
Table 3. Shoot fresh mass (S.F.M.) and shoot dry mass (S.D.M.) of Eucalyptus grandis seedlings in response to the application of different treatments with wastewater from fish farming evaluated at 60, 75, 90, 105 and 120 days after sowing. Dois Vizinhos, UTFPR, 2016.

\begin{tabular}{|c|c|c|c|c|c|}
\hline \multirow{2}{*}{ Treatments } & \multicolumn{5}{|c|}{ S.F.M. (g planta ${ }^{-1}$ ) } \\
\hline & 60 DAS & 75 DAS & 90 DAS & 105 DAS & 120 DAS \\
\hline WNS & $0.14 c^{\star}$ & $0.29^{\mathrm{ns}}$ & $1.39 \mathrm{a}$ & $4.1 \mathrm{a}$ & $4.7 \mathrm{a}$ \\
\hline DNS & $0.17 \mathrm{~b}$ & 0.29 & $1.34 \mathrm{a}$ & $3.36 \mathrm{~b}$ & $4.5 \mathrm{a}$ \\
\hline $50 \% \mathrm{FW}+\mathbf{5 0} \% \mathrm{WNS}$ & $0.20 \mathrm{a}$ & 0.32 & $1.24 \mathrm{a}$ & $3.35 \mathrm{~b}$ & $4.0 \mathrm{~b}$ \\
\hline $75 \% \mathrm{FW}+25 \% \mathrm{WNS}$ & $0.13 c$ & 0.21 & $0.84 \mathrm{~b}$ & $2.12 \mathrm{c}$ & $2.6 c$ \\
\hline FW & $0.11 \mathrm{c}$ & 0.21 & $0.39 \mathrm{c}$ & $0.39 \mathrm{~d}$ & $0.5 \mathrm{~d}$ \\
\hline Mean & 0.15 & 0.27 & 1.04 & 2.66 & 3.3 \\
\hline CV (\%) & 12.9 & 24.5 & 11.6 & 7.5 & 9.6 \\
\hline \multirow{2}{*}{ Treatments } & \multicolumn{5}{|c|}{ S.D.M. (g planta $\left.{ }^{-1}\right)$} \\
\hline & 60 DAS & 75 DAS & 90 DAS & 105 DAS & 120 DAS \\
\hline WNS & $0.03 \mathrm{~b}^{\star}$ & $0.06^{\mathrm{ns}}$ & $0.31 \mathrm{a}$ & $0.91 \mathrm{a}$ & $1.66 \mathrm{a}$ \\
\hline DNS & $0.04 \mathrm{a}$ & 0.07 & $0.30 \mathrm{a}$ & $0.74 \mathrm{~b}$ & $1.63 \mathrm{a}$ \\
\hline $50 \%$ FW + $50 \%$ WNS & $0.05 \mathrm{a}$ & 0.08 & $0.25 \mathrm{~b}$ & $0.68 \mathrm{~b}$ & $1.29 \mathrm{~b}$ \\
\hline $75 \% \mathrm{FW}+25 \% \mathrm{WNS}$ & $0.03 \mathrm{~b}$ & 0.05 & $0.18 \mathrm{c}$ & $0.48 \mathrm{c}$ & $0.89 c$ \\
\hline FW & $0.04 \mathrm{a}$ & 0.07 & $0.07 \mathrm{~d}$ & $0.08 \mathrm{~d}$ & $0.28 \mathrm{~d}$ \\
\hline Mean & 0.03 & 0.07 & 0.22 & 0.58 & 1.15 \\
\hline $\mathrm{CV}(\%)$ & 20.0 & 22.0 & 9.0 & 15.2 & 6.9 \\
\hline
\end{tabular}

WNS: weekly nutrient solution; DNS: daily nutrient solution; FW: fish wastewater; ns: no significant; CV: coefficient of variance; ${ }^{*}$ means followed by distinct letters in the column differ by the Scott Knott test at $5 \%$ probability.

With regards to root dry mass at 120 DAS, it was observed that the treatment with the highest mass was the combination of $50 \% \mathrm{FW}+50 \%$ DNS $\left(0.480 \mathrm{~g} \mathrm{plant}^{-1}\right)$ (Table 4$)$. The lower accumulation of root dry biomass was due to using the wastewater from fish farming, possibly because of lower availability of nutrients, especially nitrogen (Table 5). According to a study conducted by Salvador et al. (2012) with different concentrations of starch wastewater in the production of eucalyptus seedlings (E. grandis), the authors verified that in the root dry mass production they highlighted concentrations of 25 and $12.5 \%$ of the starch wastewater in addition to using the commercial fertilizer (Yogen $5^{\circ}$ ); as concentrations above these provided the worst conditions for root dry mass production, possibly because this residue did not meet the nutritional demand of the seedlings. The authors also report that the chemical composition of starch wastewater supports the potential of the compound as biofertilizer, as a function of the presence of potassium, nitrogen, magnesium, phosphorus, calcium, sulfur, iron and other micronutrients.
For the macronutrients, nitrogen was the mineral element extracted in greater quantity by eucalyptus seedlings, followed by potassium, calcium, magnesium, phosphorus and sulfur (Table 5). Micronutrients in descending order of extraction were iron, manganese, boron, zinc, copper and sulfur. The nutrient content bands in the dry matter of eucalyptus leaves considered adequate in $\mathrm{g} \mathrm{kg}^{-1}$ for $\mathrm{N}, \mathrm{P}, \mathrm{K}, \mathrm{Ca}, \mathrm{Mg}$ and $\mathrm{S}$, respectively, are: $13.5-18$; $0.9-1.3$; 9-13; 6-10; 3.5-5 and 1.5-2; for $\mathrm{Mn}$, $\mathrm{Zn}, \mathrm{B}, \mathrm{Cu}$ and $\mathrm{Fe}$ in $\mathrm{mg} \mathrm{kg}^{-1}$ are: 400-600, 35-50, 30-50, 7-10 and 150-200 (Gonçalves, 2005).

Considering the adequate ranges previously described, the macronutrient contents found in the leaf tissue for the studied solutions presented values below the recommended values in $\mathrm{T} 2$ and $\mathrm{T} 5$ for $\mathrm{N} ; \mathrm{T} 1$ and $\mathrm{T} 3$ for Ca; T2; T3; T4 and T5 for S (Table 5). All treatments were within the appropriate range for $\mathrm{K}$, with higher $\mathrm{K}$ content in WNS treatment. In addition, all treatments presented values above the recommended range for $\mathrm{P}$ and $\mathrm{Mg}$. Regarding the micronutrients, $\mathrm{Mn}$ and $\mathrm{Zn}$ were below the recommended levels in all treatments. They also presented concentration below recommended 
Table 4. Fresh root mass (F.R.M.) and dry root mass (D.R.M.) of Eucalyptus grandis seedlings in response to the application of different treatments with fish farming wastewater evaluated at 60, 75, 90, 105 and 120 days after sowing. Dois Vizinhos, UTFPR, 2016.

\begin{tabular}{|c|c|c|c|c|c|}
\hline \multirow{2}{*}{ Treatments } & \multicolumn{5}{|c|}{ F.R.M. (g planta ${ }^{-1}$ ) } \\
\hline & 60 DAS & 75 DAS & 90 DAS & 105 DAS & 120 DAS \\
\hline WNS & $0.02 c^{*}$ & $0.05 \mathrm{~b}$ & $0.41 \mathrm{c}$ & $1.13 \mathrm{c}$ & $1.66 \mathrm{c}$ \\
\hline DNS & $0.05 \mathrm{~b}$ & $0.08 \mathrm{~b}$ & $0.59 \mathrm{~b}$ & $1.51 \mathrm{~b}$ & $1.74 \mathrm{c}$ \\
\hline $50 \% \mathrm{FW}+\mathbf{5 0} \% \mathrm{WNS}$ & $0.09 \mathrm{a}$ & $0.16 \mathrm{a}$ & $0.79 \mathrm{a}$ & $1.91 \mathrm{a}$ & $2.45 \mathrm{a}$ \\
\hline $75 \% \mathrm{FW}+25 \% \mathrm{WNS}$ & $0.07 \mathrm{a}$ & $0.12 \mathrm{a}$ & $0.44 \mathrm{c}$ & $1.81 \mathrm{a}$ & $2.12 \mathrm{~b}$ \\
\hline FW & $0.06 \mathrm{~b}$ & $0.10 \mathrm{~b}$ & $0.22 \mathrm{~d}$ & $0.38 \mathrm{~d}$ & $0.50 \mathrm{~d}$ \\
\hline Mean & 0.06 & 0.10 & 0.49 & 1.34 & 1.69 \\
\hline CV (\%) & 32.0 & 30.6 & 25.0 & 15.6 & 10.5 \\
\hline \multirow{2}{*}{ Treatments } & & \multicolumn{4}{|c|}{ D.R.M. (g planta ${ }^{-1}$ ) } \\
\hline & 60 DAS & 75 DAS & 90 DAS & 105 DAS & 120 DAS \\
\hline WNS & $0.004 \mathrm{~b}$ & $0.007 \mathrm{~b}$ & $0.049 \mathrm{a}$ & $0.14 \mathrm{a}$ & $0.39 \mathrm{~b}$ \\
\hline DNS & $0.005 \mathrm{~b}$ & $0.008 \mathrm{~b}$ & $0.050 \mathrm{a}$ & $0.13 \mathrm{a}$ & $0.43 \mathrm{~b}$ \\
\hline $50 \%$ FW + $50 \%$ WNS & $0.004 \mathrm{~b}$ & $0.007 \mathrm{~b}$ & $0.053 \mathrm{a}$ & $0.13 \mathrm{a}$ & $0.48 \mathrm{a}$ \\
\hline $75 \%$ FW + $25 \%$ WNS & $0.003 \mathrm{~b}$ & $0.005 \mathrm{~b}$ & $0.030 \mathrm{~b}$ & $0.12 \mathrm{a}$ & $0.40 \mathrm{~b}$ \\
\hline FW & $0.012 \mathrm{a}$ & $0.019 \mathrm{a}$ & $0.022 \mathrm{~b}$ & $0.04 \mathrm{~b}$ & $0.22 \mathrm{c}$ \\
\hline Mean & 0.005 & 0.009 & 0.04 & 0.11 & 0.38 \\
\hline CV (\%) & 30.3 & 34.4 & 24.5 & 35.5 & 10.16 \\
\hline
\end{tabular}

WNS: weekly nutrient solution; DNS: daily nutrient solution; FW: fish wastewater; CV: coefficient of variance; ${ }^{*}$ means followed by distinct letters in the column differ by the Scott Knott test at $5 \%$ probability.

in T1 and T2 treatment for Cu. Lastly, elements B and Fe were within or above the appropriate range.

It can be observed that the wastewater concentration had adequate nutrient contents for seedling growth, except for $\mathrm{N}, \mathrm{Mn}$ and $\mathrm{Z}$, and that the use of this waste can represent an important possibility in the intensive production of fish associated to seedling production in nurseries as a way of using waste (fish excrement and food leftovers), aiming to make the seedling production more sustainable and integrating the production of two activities, which results in greater diversity of products or non-exploited resources.

Similar results were observed by Nogueira Filho et al. (2003) when they investigated the development of lettuce grown in a NFT hydroponic system with fish pond water in a superintensive closed system with tilapia,

Table 5. Nitrogen $(\mathrm{N})$, phosphorus $(\mathrm{P})$, potassium $(\mathrm{K})$, calcium $(\mathrm{Ca})$, magnesium $(\mathrm{Mg})$, sulfur $(\mathrm{S})$, boron $(\mathrm{B})$, copper $(\mathrm{Cu})$, iron $(\mathrm{Fe})$, manganese $(\mathrm{Mn})$ and zinc $(\mathrm{Zn})$ levels of eucalyptus leaves as a function of different treatments with wastewater from fish farming. Dois Vizinhos, UTFPR, 2016.

\begin{tabular}{|c|c|c|c|c|c|c|c|c|c|c|c|}
\hline Treat. & $\mathbf{N}$ & $\mathbf{P}$ & $\mathbf{K}$ & $\mathrm{Ca}$ & Mg & $\mathbf{S}$ & B & $\mathrm{Cu}$ & $\mathrm{Fe}$ & Mn & $\mathrm{Zn}$ \\
\hline & \multicolumn{6}{|c|}{ 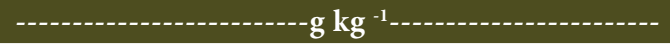 } & \multicolumn{5}{|c|}{ 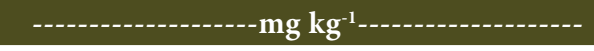 } \\
\hline T1 & $20.56 \mathrm{a}^{*}$ & $1.35 \mathrm{~b}$ & $12.83 \mathrm{a}$ & $5.21 \mathrm{~b}$ & $3.93 \mathrm{~b}$ & $2.30 \mathrm{a}$ & $30.06 \mathrm{~d}$ & $4.61 \mathrm{~b}$ & $195.0 \mathrm{c}$ & 202.13 c & $21.68 \mathrm{~b}$ \\
\hline T2 & $12.71 \mathrm{c}$ & $1.32 \mathrm{~b}$ & $9.62 \mathrm{c}$ & $8.56 \mathrm{a}$ & $6.46 \mathrm{a}$ & $1.07 \mathrm{c}$ & 48.47 e & $5.57 \mathrm{~b}$ & $535.0 \mathrm{~b}$ & $322.02 \mathrm{a}$ & $34.28 \mathrm{a}$ \\
\hline T3 & $17.90 \mathrm{~b}$ & $1.96 \mathrm{a}$ & $10.36 \mathrm{c}$ & $5.52 \mathrm{~b}$ & $4.01 \mathrm{~b}$ & $1.36 \mathrm{~b}$ & $141.02 \mathrm{a}$ & $7.44 \mathrm{~b}$ & $210.4 \mathrm{c}$ & $122.51 \mathrm{e}$ & $17.75 \mathrm{c}$ \\
\hline T4 & $16.49 \mathrm{~b}$ & $1.74 \mathrm{a}$ & $11.37 \mathrm{~b}$ & $8.68 \mathrm{a}$ & $5.65 \mathrm{a}$ & $1.22 \mathrm{~b}$ & $91.96 \mathrm{~b}$ & $9.51 \mathrm{a}$ & $1319.0 \mathrm{a}$ & $167.88 \mathrm{~d}$ & $22.82 \mathrm{~b}$ \\
\hline T5 & $13.05 \mathrm{c}$ & $1.65 \mathrm{~b}$ & $11.40 \mathrm{~b}$ & $8.06 \mathrm{a}$ & $5.72 \mathrm{a}$ & $1.04 \mathrm{c}$ & $76.41 \mathrm{a}$ & $13.34 \mathrm{a}$ & $1485.5 \mathrm{a}$ & 229.95 b & $23.08 \mathrm{~b}$ \\
\hline Mean & 16.14 & 1.60 & 10.91 & 7.21 & 5.16 & 1.40 & 76.54 & 8.09 & 849.14 & 208.90 & 23.92 \\
\hline C.V. (\%) & 3.86 & 9.21 & 3.32 & 3.17 & 5.58 & 4.32 & 1.16 & 23.21 & 25.66 & 2.58 & 2.20 \\
\hline
\end{tabular}

T1: weekly nutrient solution; T2: daily nutrient solution; T3: 50\% FW + 50\% WNS; T4: 75\% FW + 25\% WNS; T5: fish wastewater; CV: coefficient of variance; ${ }^{*}$ means followed by distinct letters in the column differ by the Scott Knott test at $5 \%$ probability. 
and found that plants cultivated with wastewater only resulted in lower fresh mass production and nutrient concentration in the leaves, except for $\mathrm{Ca}, \mathrm{Mg}, \mathrm{B}$ and $\mathrm{Fe}$, while cultivars with wastewater $+25 \%$ of Castellane \& Araújo (1994) nutrient solution presented a fresh mass equivalent to $100 \%$ of the Castellane \& Araújo (1994) nutrient solution.

In evaluations of the chemical characteristics of wastewater from an intensive fish farming system aiming at its possible use in the cultivation of three lettuce cultivars in hydroponics, Cortez et al. (2009) verified that the matrinxã breeding system was not able to generate (using fish excrements and food leftovers) dissolved residues with adequate potassium and magnesium levels for hydroponic lettuce cultivation, making mineral supplementation opportune in order to enable good development of the plants.

\section{CONCLUSIONS}

The best growth and development results of Eucalyptus grandis seedlings were found in the treatments which used chemical fertilization.

The use of the combination 50\% FW + 50\% DNS presented significant results in terms of eucalyptus seedling quality, similar to those fertigated with nutrient solution only. Fertigation with only wastewater from fish farming resulted in lower growth and development of seedlings.

Fish wastewater can be used in combination with nutrient solutions, which may represent an alternative to reuse in the production of Eucalyptus grandis seedlings, reducing the environmental impact of effluent from this type of animal production.

\section{SUBMISSION STATUS}

Received: 6 May, 2017

Accepted: 24 Nov., 2018

\section{CORRESPONDENCE TO}

\section{Dalva Paulus}

Universidade Tecnológica Federal do Paraná, Estrada para Boa Esperança, $\mathrm{km} \mathrm{4,}$ CEP 85660-000, Dois Vizinhos, PR, Brasil e-mail: dalvapaulus@utfpr.edu.br

\section{FINANCIAL SUPPORT}

Conselho Nacional de Desenvolvimento Científico e Tecnológico (CNPq).

\section{REFERENCES}

Araújo AP, Machado CTT. Fósforo. In: Fernandes MS, editor. Nutrição mineral de plantas. Viçosa: Sociedade Brasileira de Ciência do Solo; 2006. p. 253-280.

Assenheimer A. Benefícios do uso de biossólidos como substratos na produção de mudas de espécies florestais. Ambiência 2009 [cited 2019 May 24]; 5(2): 321-330. Available from: https://bit.ly/2Qpd2qO

Castellane PD, Araújo JAC. Cultivo sem solo: hidroponia. Jaboticabal: Funep; 1994.

Carmo ER, Silva CF, Freitas MSM, Lima KB, Martins MA. Production of Australian cedar seedlings inoculated with arbuscular mycorrhizal fungi in different types of containers. Revista Árvore 2016; 40(2): 269-278. 10.1590/0100-67622016000200009

Ceconi DE, Poletto I, Brun EJ, Lovato T. Crescimento de mudas de açoita-cavalo (Luehea divaricata Mart.) sob influência da adubação fosfatada. Cerne 2006 [cited 2019 May 24]; 12(3): 292-299. Available from: https:// bit.ly/2HA6Rxi

Cerqueira PHA, Azevedo GB, Souza AM, Sousa Azevedo GTOS. Adubação residual na produção de mudas clonais de eucalipto. Pesquisa Florestal Brasileira 2017; 37(90): 119-129. 10.4336/2017.pfb.37.90.934

Cortez GEP, Araújo JAC, Bellingieri PA, Dalri AB. Qualidade química da água residual da criação de peixes para cultivo de alface em hidroponia. Revista Brasileira de Engenharia Agrícola e Ambiental 2009; 13(4): 494-498. 10.1590/S1415-43662009000400019

Dickson A, Leaf AL, Hosner JF. Quality appraisal of white spruce and whitepine seedling stock in nurseries. The Forestry Chronicle 1960; 36(1): 10-13. 10.5558/tfc36010-1

Dye PJ, Jacobs S, Drew D. Verification of 3-PG growth and water-use predictions in twelve Eucalyptus plantation stands in Zululand, South Africa. Forest Ecology and Management 2004; 193: 197-218. 10.1016/j. foreco.2004.01.030

Gomes JM, Couto L, Leite HG, Xavier A, Garcia SLR. Parâmetros morfológicos na avaliação da qualidade de mudas de Eucalyptus grandis. Revista Árvore 2002; 26(6): 655-664. 10.1590/S0100-67622002000600002

Gomes JM, Paiva HN. Viveiros florestais: propagação sexuada. 3rd ed. Viçosa: UFV; 2004.

Gonçalves JLM. Recomendações de adubação para Eucalyptus, Pinus e espécies nativas. 2005 [cited 2016 Feb. 28]. Available from: https://bit.ly/2Wmj6FD 
Gonçalves JLM, Wichert MCP, Gava JL, Serrano MIP. Soil fertility and growth of Eucalyptus grandis in Brazil under different residue management practices. In: Nambiar EKS, editor. Site management and productivity in tropical plantation forests. Bogor: CIFOR; 2008. p. 51-62. 10.17528/ cifor/002517

Kozlowski TT, Kramer PJ, Pallardy SG. The physiological ecology of woody plants. New York: Academic Press; 1991.

Kratz D, Wendling I. Produção de mudas de Eucalyptus dunnii em substratos renováveis. Floresta 2013; 43(1): 125-136. 10.5380/rf.v43i1.25989

Malavolta E, Vitti GC, Oliveira SA. Avaliação do estado nutricional das plantas: princípios e aplicações. 2nd ed. Piracicaba: Associação Brasileira para Pesquisa da Potassa e do Fosfato; 1997.

Mariscal-Lagarda MM, Páez-Osuna F, Esquer-Méndez JL, Guerrero-Monroy I, Romo de Vivar A, Felix-Gastelum R. Integrated culture of white shrimp (Litopenaeus vannamei) and tomato (Lycopersicon esculentum Mill) with low salinity groundwater: management and production. Aquaculture 2012; 367: 76-84. 10.1016/j. aquaculture.2012.09.003

Martins FB, Silva JC, Streck NA. Estimativa da temperatura-base para emissão de folhas e do filocrono em duas espécies de eucalipto na fase de muda. Revista Árvore 2007; 31(3): 373-381. 10.1590/S0100-67622007000300002

Nogueira Filho H, Santos O, Borcioni E, Sinchak S, Puntel R. Aquaponia: interação entre alface hidropônica e criação superintensiva de tilápias. Horticultura Brasileira 2003; 21(2): 1-4

Pinto SIC, Furtini Neto AE, Neves JCL, Faquin V, Moretti BS. Eficiência nutricional de clones de eucalipto na fase de mudas cultivados em solução nutritiva. Revista Brasileira de Ciência do Solo 2011; 35(2): 523-533. 10.1590/S010006832011000200021

Reis ER, Lúcio AD, Fortes FO, Lopes SJ, Silveira BD. Período de permanência de mudas de Eucalyptus grandis em viveiro baseado em parâmetros morfológicos. Revista Árvore 2008; 32(5): 809-814. 10.1590/S010067622008000500004

Rocha SA, Garcia GO, Lougon MS, Cecílio RA, Caldeira MVW. Crescimento e nutrição foliar de mudas de Eucalyptus sp. irrigadas com diferentes qualidades de água. Revista de Ciências Agrárias 2014 [cited 2019 May 23]; 37(2): 141-151. Available from: https://bit.ly/2JBHBc3

Rodrigues DS, Leonardo AFG, Nomura ES, Tachibana L, Garcia VA, Correa CF. Produção de mudas de tomateiro em sistemas flutuantes com adubos químicos e água residuária de viveiros de piscicultura. Revista Brasileira de Ciências Agrárias 2010; 5(1): 32-35. 10.5039/agraria. v5i1a567

Salvador MA, José JV, Rezende JR, Oliveira HV, Gava R. Aplicação de efluente líquido de fecularia em substratos e solos para a produção de mudas de eucalipto. Revista em Agronegócios e Meio Ambiente 2012 [cited 2019 May 23]; 5(1): 175-188. Available from: https://bit.ly/2EvU1y2

Silva RBG, Simões D, Silva MR. Qualidade de mudas clonais de Eucalyptus urophylla $\times$ E. grandis em função do substrato. Revista Brasileira de Engenharia Agrícola Ambiental 2012; 16(3): 297-302. 10.1590/S141543662012000300010

Silveira RLVA, Luca EF, Silveira LVA, Luz HF. Matéria seca, concentração e acúmulo de nutrientes em mudas de Eucalyptus grandis em função da idade. Scientia Florestalis 2003 [cited 2019 May 24]; 64: 136-149. Available from: https://bit.ly/2YKhiE7

Simões D, Silva MR. Análise técnica e econômica das etapas de produção de mudas de eucalipto. Cerne 2010 [cited 2019 May 24]; 16(3): 359-366. Available from: https://bit.ly/2VOFiEj

Wendling I, Dutra LF. Produção de mudas de eucalipto por sementes. In: Wendling I, Dutra, LF, editors. Produção de mudas de eucalipto. Colombo: Embrapa Florestas; 2010. p. 13-47. 